\title{
Gender Differences in Formal Thinking: Their Impact on Right-Wing Authoritarianism and Religious Fundamentalism
}

\author{
K. Robert Bridges, Richard J. Harnish \\ Department of Psychology, The Pennsylvania State University, New Kensington Campus, New Kensington, PA, \\ USA \\ Email: krb3@psu.edu
}

Received 28 August 2015; accepted 16 October 2015; published 19 October 2015

Copyright (C) 2015 by authors and Scientific Research Publishing Inc.

This work is licensed under the Creative Commons Attribution International License (CC BY). http://creativecommons.org/licenses/by/4.0/

(c) (i) Open Access

\section{Abstract}

The present study investigated the relationship between cognitive development and political and religious ideology, and whether there are gender differences in formal thinking which may be related to right-wing authoritarianism and religious fundamentalism. The conceptual and empirical literature suggests that many aspects of cognition which play a role in the formation of conservative political and religious ideology are also present in those who engage in Piagetian concrete thinking (versus formal thought). The sample consisted of $\mathbf{1 1 6}$ late adolescents and young adults enrolled at a large public university. Results found that only $40 \%$ of participants had achieved formal thought on a traditional test of formal thinking, and that women who had lower scores on this test scored higher on measures of right-wing authoritarianism and religious fundamentalism. There was no such relationship for men. The present study shows the value of this approach and suggests the need for a pragmatic test of formal thought focused on political and religious ideologies.

\section{Keywords}

Formal Reasoning, Right-Wing Authoritarianism, Religiosity

\section{Introduction}

With the increasing political and ideological polarization in America (Mundy, 2004; Seyle \& Newman, 2006), we thought it was important to try to gain a better understanding of the cognitive variables linked to the conflict 
between political and religious groups, which as Mundy observed are more intractable than ever. As a consequence of the re-emergence of ideology as an important topic of inquiry among personality and social psychologists (Jost, Federico, \& Napier, 2009), there is an exciting body of research scattered over a wide range of journals, books, and many subfields of psychology. However, there does not seem to be a guiding conceptual framework to integrate this research.

After the seminal 1950 study of authoritarianism (Adorno, Frankel-Brunswik, Levinson, \& Sanford, 1950) an extensive literature developed comparing the cognitive style, cognitive ability, personality and motivational variables of political conservatives with moderates and liberals. Although the focus on right-wing authoritarianism was initially heavily criticized, Jost, Glaser, Kuglanski, \& Sulloway (2003) argued that "it has withstood the relentless tests of time and empirical scrutiny" (p. 339) and that there continues to be a measurable link between politically conservative attitudes and a clearly defined set of psychological properties. A close examination of this literature suggests that the cognitive profiles of liberals and conservatives differ markedly. Among the cognitive variables which have been linked to conservatism are cognitive closure and complexity (Chirumbolo, 2002), cognitive inferiority (McCourt, Bouchard, Lykken, Tellegren, \& Keyes, 1999), and cognitive sophistication (Bobo \& Licari, 1989; Sidanius, Pratto, \& Bobo, 1996).

Cognitive ability and cognitive style have also been linked to political conservatism. Cognitive ability or cognitive skill has been characterized as multidimensional abilities, such as language, memory, and intelligence. For example, Heaven, Ciarrochi, \& Leeson (2011) reported that right-wing authoritarianism was predicted by low cognitive ability, defined as $g$ (i.e., scores on school-based cognitive ability tests and verbal intelligence). Similarly, investigators have reported a negative correlation between conservatism and cognitive ability, conceived as vocabulary and analogy test scores (Stankov, 2009), and verbal ability (Kemmelmeirer, 2008). Conversely, Schoon, Cheng, Gale, Batty, \& Deary (2010) reported that cognitive ability, defined as $g$ at age 11 (based on an unspecified general ability test of verbal and non-verbal abilities) positively correlated with liberal social attitudes.

Cognitive style refers to cognitive functioning, particularly with respect to learning preference, and information processing style. Tetlock (1983), utilizing a processing model, found that conservative politicians made significantly less complex statements compared to their liberal colleagues; Chirumbolo (2002) found that both cognitive style, defined as a need for cognitive closure, and authoritarianism, are associated with a right-wing political orientation.

While an examination of the literature of ideology suggests that many aspects of cognition are involved in its formation, it appears that thus far investigators have not examined the role of cognitive maturity as a conceptual framework upon which to integrate this voluminous body of work. However, this literature revealed a number of cognitive abilities included in Piaget's model (Inhelder \& Piaget, 1958), which may play an integral role in the development of these ideologies. Piaget proposed that cognitive development proceeds through a series of revolutionary changes, culminating in hypothetical reasoning and abstract thought. Research by Emler, Renwick, \& Malone (1983) provided an intriguing hint of the value of this approach; they found that those with liberal leanings are more likely to reason at Kohlberg's (1969) postconventional level, whereas conservatives are more likely to reason in conventional terms. This indicated a cognitive developmental difference between those who reject and those who accept conservative attitudes. Kohlberg's theory of moral reasoning was based on and related to advances in cognitive development first described by Piaget (Krebs \& Denton, 2005). More recent research (Hodson \& Busseri, 2012) found that cognitive ability, characterized as poor abstract reasoning skills (a central component of Piagetian theory), plays a substantial role in predicting right-wing ideologies and authoritarian value systems.

Piaget proposed that there was a qualitative shift in thinking during adolescence from concrete to formal operational thought (Piaget, 1970). The central features of formal thought include the ability to distinguish between reality and possibility, and the ability to develop hypotheses to explain an event and then to follow the premise to its logical conclusion. There are other skills which emerge during the stage of formal thought as well (Newman \& Newman, 2007). They are: 1) the ability to cognitively manipulate more than two categories of variables at the same time; 2) the ability to think about things changing in the future; 3) the ability to think about a logical sequence of possible events; 4) the ability to anticipate the consequences of behavior; 5) the capacity to detect the logical consistency or inconsistency in a set of statements; and 6) the ability to think in a relativistic way about individuals and groups. Additionally, the transition to formal operations involves the decline of egocentrism and the development of decentering, an ability to realize that an individual's ideas are not shared by all 
others in a pluralistic society (Newman \& Newman, 2007). Consequently, individuals who engage in formal thinking are able to accept members of other cultures, because they understand that they are a product of different cultural rules and norms.

From this it appears that formal thought encompasses many of the traits associated with more moderate ideological thinking. Durrheim (1997) noted that a central feature of authoritarianism is a rigid, black-white style of cognition not ulitized by formal thinkers. Further, Ekehammar, Akrami, Gylje, \& Zakrisson (2004) observed that right-wing authoritarianism is a construct that includes ethnocentrism and aggression to outgroups, which Hofstede (1991) argued is to a group what egocentrism is to an individual. Reykowski \& de Zavala (2006) suggested that ethnocentrism is a transient phenomenon that should disappear with cognitive development, not just increasing age. Yet in many adults this is not transient; investigators (e.g., Altemeyer, 1998; Crowson, DeBacker, \& Thoma, 2005) have found that individuals scoring high in right-wing authoritarianism demonstrate heightened levels of prejudice toward ethnic and sexual minorities, and that they are more likely to support restrictions on human rights, have fundamentalist religious beliefs, and exhibit religious ethnocentrism. Indeed, Brandt \& Reyna (2010) noted that religious fundamentalism has been linked to prejudice toward a variety of out-groups.

Altemeyer \& Hunsberger (1992) reported that people high in right-wing authoritarianism tend to be highly punitive and favor physical punishment during childrearing. This is significant because in both Piaget's (Kail, 2012) and Kohlberg's (1969) theory of moral development, moral reasoning in its earliest stages is based on the use of and fear of punishment. After reviewing the multitude of cognitive properties which have been linked to right-wing authoritarianism and religious fundamentalism, it appeared to us that cognitive developmental theory, specifically whether or not an individual had achieved formal thought, may be the conceptual framework to integrate much of the research which attempted to understand political and religious ideology. As Newman \& Newman (2007) explained, formal thinking makes possible the development of abstract and systematic thought, resulting in a more complex approach to the analysis of new information, abilities not available to individuals who have not advanced beyond the concrete operational stage.

One criticism of Piaget's cognitive developmental theory is that it originally overestimated the number of adolescents and adults who engage in formal thought (Newman \& Newman, 2007). Inhelder \& Piaget (1958) believed that most adolescents become capable of formal thinking between the ages of 12 and 16 years. While there is now a consensus among developmental cognition theorists and investigators that formal thinking exists and involves mature, scientific reasoning (Newman \& Newman, 2007), research has revealed that many adolescents and adults do not function at the level of formal thought. For example, Reyes (1987) found that in a sample of American undergraduates, 45\% had not begun the transition to formal thinking. It may be that late adolescents and adults who do not engage in formal thought will adhere to different ideologies than those who do.

It is within this context that we sought to determine how many present day adolescents and young adults have achieved formal thought, and to examine the relationship of formal thinking to right-wing authoritarianism and religiosity. The conceptual and empirical literature led us to anticipate that those individuals who with lower scores in formal thinking would be more likely to exhibit higher scores on right-wing authoritarianism and fundamentalist religiosity.

Another suggested shortcoming of Piaget's theory is that it undervalues the influence of social and cultural forces (Kail, 2012). Consequently, a second goal of the study was to explore how right-wing authoritarianism and religious fundamentalism may reflect individual experience and socialization. Unger, Draper, \& Pendergrass (1986) have argued that personal epistemologty is related to these experiential variables; they suggested that individuals vary in the degree to which they hold a belief in logical positivism (i.e., that reality is fixed and objectively accessible), and social constructivism (i.e., that reality is more relativistic and reflexive). Unger et al. found that those who score high in social constructivism have a world view which holds that multiple interpretations of reality are equally valid; conversely, Jost et al. (2003), as noted earlier, reported that conservatives are more likely to display an intolerance of ambiguity. Further, Jackson \& Jeffers (1989) observed that individuals with higher grade point averages, reflective of cognitive ability, scored lower in logical positivism. From this, we predicted that those who scored high in right-wing authoritarianism and religious fundamentalism would score higher in logical positivism than social constructivism. This takes on added significance in that Jackson \& Jeffers (1989) argued that group differences in personal epistemology can impede communication between groups, which could account in part for the ideological polarization noted above.

Finally, we wished to explore gender differences in formal thinking and how it might impact right-wing au- 
thoritarianism and religious fundamentalism. In a meta-analysis of 53 studies of gender differences in formal thought, Meehan (1984) found that men exhibited better performance on formal tasks than women. However, Cole, Cole, \& Lightfoot (2005) reported that gender differences have declined during the previous 20 years, in part because women have been encouraged to participate more in math and science fields. We therefore predicted that men would score higher in a test of formal thinking, but that the difference would be relatively small.

\section{Method}

\subsection{Participants}

Respondents in this study were 116 undergraduate students (77 women, 39 men) enrolled in introductory psychology at a large, northeastern public university in the U.S. The mean age of students was $20.32(S D=4.82)$; $53 \%$ of students were in their first year of college while $47 \%$ were in their second or later year. The study was approved by the university's Institutional Review Board, and all of the students consented to the study.

\subsection{Apparatus}

The study was administered using CheckBox Survey Software (Prezza Technologies, 2010) on Dell Optiplex 960 personal computers.

\subsection{Measures}

The Arlin (1984) Test of Formal Reasoning (ATFR) was developed to determine an individual's level of cognitive development based the Piagetian theory of an invariant sequence of cognitive stages. The ATFR assesses abilities associated with the last two of Piaget's cognitive stages and is subdivided into the following categories: concrete, high concrete, transitional, low formal, and high formal. Higher scores on the ATFR indicate a higher level of cognitive ability. Participants' scores on the ATFR ranged from 4 to 28.

The Right-Wing Authoritarian Scale (RWAS; Altemeyer, 2006) consists of 22-items which are rated on a 9 -point scale where $-4=$ very strongly disagree, $0=$ neutral, and $+4=$ very strongly agree. The RWAS measures an individual's tendency to submit to authority and to be hostile and punitive to those who do not. Higher scores on the RWAS indicate a greater willingness to submit to authority. Participants' scores on the RWAS ranged from 22 to 143. The observed Cronbach's Alpha for the RWAS in this study was .92.

The Revised Religious Fundamentalism Scale (RFS; Altemeyer \& Hunsberger, 2004) consists of 12 items, each rated on an 8 -point scale where $-4=$ very strongly disagree and $+4=$ very strongly agree. The RFS measures the belief that there is one inerrant set of religious teachings that contain the fundamental truth about humanity and deity. Higher scores on the revised RFS indicate higher religious fundamentalism. Participants' scores on the revised RFS ranged from 12 to 100. The observed Cronbach's Alpha for the RFS in this study was .94.

Attitudes About Reality Scale (AARS; Unger, Draper, \& Pendergrass, 1986) measures personal epistemology regarding science and knowledge. It assesses the degree to which a person believes that reality is objectively knowable (positivist) or socially constructed (relativist). The AARS short form consists of 28-items rated on a seven-point scale where 1 = strongly agree with the statement; $4=$ neutral about a statement, and $7=$ strongly disagree with the statement. Higher scores on the AARS indicate a positivist view of reality. Participants' scores on the short form of the AARS ranged from 85 to 159. The observed Cronbach's Alpha for the AARS in this study was .71.

\section{Results}

Table 1 contains the proportion of our participants who scored at each of the five levels measured by the ATFR. As can be seen, only 46 of 116 (40\%) had achieved formal thought at either the low or high formal level. This is more optimistic than the results of Bradmetz (1999); while using the Schirks (1970) Test of Formal Thought, he found that less than $2 \%$ of a sample of European adolescents had achieved formal thought by age 15 .

Additionally, we observed a gender difference such that men scored higher on the ATFR $(M=17.87, S D=$ $6.21)$ than women $(M=14.80, S D=5.37), t(114)=2.76, p=.007$, partial eta squared $=0.06$. Because of the observed gender difference in scores on the ATFR, we explored this difference in more detail and discovered 
unequal cell sizes for the five Piagetian categories (i.e., concrete, high concrete, transitional, low formal, and high formal operations). See Table 2. Because of this, we decided to perform a median split on the ATFR where scores less than 16 were classified as low in operations and scores higher than 15 were classified as high in operations. Means and standard deviations of the study variables are presented in Table 3.

Table 1. Distribution of cognitive stage as measured by ATFR scores.

\begin{tabular}{cc}
\hline Cognitive Stage & Percent of Participants \\
\hline Concrete & 8 \\
High concrete & 37 \\
Transitional & 15 \\
Low formal & 31 \\
High formal & 9 \\
\hline
\end{tabular}

Table 2. Distribution of gender and cognitive stage as measured by ATFR scores.

\begin{tabular}{ccc}
\hline Cognitive Stage & Percent of Men & Percent of Women \\
\hline Concrete & 8 & 8 \\
High concrete & 26 & 43 \\
Transitional & 10 & 27 \\
Low formal & 38 & 5 \\
High formal & 18 & \\
\hline
\end{tabular}

Table 3. Means and standard deviations of men and women by cognitive classification on RWAS, RFS, and AARS scores.

\begin{tabular}{|c|c|c|c|c|c|}
\hline Scale & Gender & Cognition & $M$ & $S D$ & $n$ \\
\hline \multicolumn{6}{|l|}{ RWAS } \\
\hline & Men & Low & 80.53 & 19.06 & 15 \\
\hline & Men & High & 93.50 & 29.26 & 24 \\
\hline & Women & Low & 89.38 & 21.87 & 42 \\
\hline & Women & High & 76.29 & 31.76 & 35 \\
\hline \multicolumn{6}{|l|}{ RFS } \\
\hline & Men & Low & 50.80 & 18.06 & 15 \\
\hline & Men & High & 59.63 & 27.64 & 24 \\
\hline & Women & Low & 58.57 & 19.53 & 42 \\
\hline & Women & High & 49.09 & 24.66 & 35 \\
\hline \multicolumn{6}{|l|}{ AARS } \\
\hline & Men & Low & 156.07 & 8.64 & 15 \\
\hline & Men & High & 156.63 & 12.44 & 24 \\
\hline & Women & Low & 158.67 & 13.61 & 42 \\
\hline & Women & High & 151.91 & 16.28 & 35 \\
\hline
\end{tabular}


To test our hypothesis that those who scored higher on the ATFR would score lower in right-wing authoritarianism, a 2 (Gender: Male, Female) $\times 2$ (Cognition: High, Low) ANOVA was conducted. Results revealed a significant interaction effect between gender and ATFR scores on right wing authoritarian scores, $F(1,112)=$ $6.02, p=0.02$, partial eta squared $=0.05$. Simple main effects analysis indicated that women who scored higher on the ATFR scored lower in right-wing authoritarianism $(M=76.29, S D=31.76)$ than women who scored lower on the ATFR $(M=89.38, S D=21.87), F(1,75)=4.55, p=0.04$, partial eta squared $=0.06$. Simple main effects analysis indicated no differences between men who scored higher or lower on the ATFR in right-wing authoritarianism, $p=0.14$.

In order to test our prediction that those who achieved higher scores on the ATFR would score lower in religious fundamentalism, a 2 (Gender: Male, Female) $\times 2$ (Cognition: High, Low) ANOVA was conducted on religious fundamentalism scores. Results indicated a significant interaction effect between gender and ATFR scores, $F(1,112)=4.00, p=0.05$, partial eta squared $=0.05$. Simple main effects analysis indicated that women who scored higher on the ATFR scored lower in religious fundamentalism $(M=49.09, S D=24.66)$ than women who scored lower on the ATFR $(M=58.57, S D=19.53), F(1,75)=3.55, p=0.06$, partial eta squared $=0.05$. Simple main effects analysis indicated no differences between men who scored higher or lower on the ATFR in religious fundamentalism, $p=0.28$.

To test our hypothesis that those with higher ATFR scores would score lower in logical positivism, a 2 (Gender: Male, Female) $\times 2$ (Cognition: High, Low) ANOVA was conducted on scores from the ARS. Results indicated a significant interaction effect between gender and cognition, $F(1,112)=5.20, p=0.02$, partial eta squared $=0.04$. Simple main effects analysis indicated that women who scored higher on the ATFR scored lower in logical positivism $(M=110.03, S D=13.44)$ than women who scored lower on the ATFR $(M=116.17, S D$ $=13.56), F(1,75)=3.95, p=0.05$, partial eta squared $=0.05$. Simple main effects analysis indicated no differences between men who scored higher or lower on the ATFR in logical positivism, $p=0.14$.

Finally, to test our expectation that those who scored higher in religious fundamentalism would score higher in logical positivism, a 2 (Gender: Male, Female) $\times 2$ (Religious Fundamentalism: High, Low) ANOVA was conducted on scores from the ARS. Results indicated a significant main effect for religious fundamentalism, $F(1$, $112)=8.04, p=0.005$, partial eta squared $=0.07$ such that those who scored high in religious fundamentalism scored higher in logical positivism $(M=116.53, S D=12.55)$ than those who scored low in religious fundamentalism $(M=109.47, S D=12.51)$.

\section{Discussion}

In our attempt to add to the understanding of the development of individual differences in political and religious ideology, we examined the role of Piagetian cognitive development as a contributing factor. Although Piaget's theory was the first major theory of cognitive development, a substantial body of research generated by his findings, particularly the sequence in which concepts are acquired, has generally confirmed his work (Miller, 2010). From the results of the present study, it appears that cognitive development has important implications for the development of right-wing authoritarianism, religious fundamentalism, and logical positivism. We should note that it is becoming clearer that cultural and social influences such as education can meaningfully impact Piagetian-like cognitive development (Miller, 2010); older individuals lacking a concept can acquire it from training and instruction. This takes on added significance in that since the early 1990s, educational research has experienced a paradigm shift from providing instruction to producing student learning (Umbach \& Wawrzynski, 2005). High on the recommended list of methods to promote learning are active and collaborative learning, and higher-order cognitive activities. Therefore, we were disappointed and a little surprised that the proportion of late adolescents and young adults who have achieved formal thought has changed little and remains much lower than Piaget theorized.

Newman \& Newman (2007) speculated why this is still the case; chief among those factors placing many individuals at risk for failing to develop formal thought is a learning environment that remains overly authoritarian and lacking in active learning opportunities. This results in a rigid approach to rules and strategies for problem solving rather than a deep level of understanding about the use of logic to solve complex problems. The emphasis on rote memorization and repetition of rules and strategies diminishes the basis for logico-mathematical reasoning. Not unexpectedly, research has shown that rule-following predicts right-wing conservatism (Thorisdottir, Jost, Liviatan, \& Shrout, 2007). 
The present study found gender differences in formal thinking; men scored higher on the ATFR than did women lending support to prior research that demonstrated gender differences (e.g., Meehan, 1984). The observed effect size indicated that the difference in scores between men and women on the ATFR was small as expected. Indeed, in a meta-analysis of gender differences in formal operations, Meehan (1984) found that 1\% $5 \%$ of the variance on tests of thought is explained by gender. Perhaps more interesting are within gender differences in cognition. Women who scored higher in cognitive development scored lower on our dependent measures of right-wing authoritarianism, religious fundamentalism, and logical positivism than those with low scores. Among men, there were no observed differences between those who scored high or low in cognitive development.

Piaget's theory continues to have a broad-based, invisible influence; it is now simply assumed that children and adolescents actively construct knowledge (Miller, 2010). However, Piaget's theory has been criticized because his descriptions of formal thought are too narrow; that is, they do not incorporate many other dimensions along which formal thought matures, such as understanding the strategies that are the most likely to be successful to solve a complex problem, and the ability to delay reaching a conclusion while all alternative solutions are examined (Newman \& Newman, 2007). Indeed, research on formal thought has been criticized for its lack of relevance and familiarity for adults. Instead, the standard Piagetian tasks are dominated by the role of pure logic, disconnected from a specific situation without a pragmatic focus. Tests to measure formal thought typically require that many variables are manipulated, which results in one correct solution, whereas in adult life problems involve multiple, poorly defined variables and more than one solution. Consequently, it may be that the tests currently available to measure formal thinking, which emphasize problems that have a scientific focus may not be the best approach to understand the formation of political and religious ideology. We believe that creating a test which has relevance and familiarity for adults, and which measures formal thinking with a specific focus on political and religious issues would better assess gender differences and would more clearly determine the influence of cognitive development on the formation of ideology and ideological entrenchment.

\section{Acknowledgements}

We wish to acknowledge helpful comments from Michele Bridges on an earlier draft of this manuscript.

\section{References}

Adorno, T. W., Frankel-Brunswik, E., Levinson, D. J., \& Sanford, R.W. (1950). The Authoritarian Personality. New York, NY: Harper.

Altemeyer, R. A. (1998). The Other “Authoritarian Personality.” In M. P. Zanna (Ed.), Advances in Experimental Social Psychology (pp. 47-91). San Diego: Academic Press. http://dx.doi.org/10.1016/s0065-2601(08)60382-2

Altemeyer, R. A. (2006). The Authoritarians. http://members.shaw.ca/jeanaltemeyer/drbob/TheAuthoritarians.pdf

Altemeyer, R. A., \& Hunsberger, B. (1992). Authoritarianism, Religious Fundamentalism, Quest, and Prejudice. International Journal for the Psychology of Religion, 2, 113-133. http://dx.doi.org/10.1207/s15327582ijpr0202_5

Altemeyer, R. A., \& Hunsberger, B. (2004). A Revised Religious Fundamentalism Scale: The Short and Sweet of It. International Journal for the Psychology of Religion, 14, 47-54. http://dx.doi.org/10.1207/s15327582ijpr1401 4

Arlin, P. K. (1984). Arlin Test of Formal Reasoning: Test Manual. East Auroa, NY: Slosson Educational.

Bobo, L., \& Licari, F. C. (1989). Education and Political Tolerance: Testing the Effects of Cognitive Sophistication and Target Group Affect. Public Opinion Quarterly, 53, 285-308. http://dx.doi.org/10.1086/269154

Bradmetz, J. (1999). Precursors of Formal Thought: A Longitudinal Study. British Journal of Developmental Psychology, 17, 61-81. http://dx.doi.org/10.1348/026151099165159

Brandt, M. J., \& Reyna, C. (2010). The Role of Prejudice and the Need for Closure in Religious Fundamentalism. Personality and Social Psychology Bulletin, 36, 715-725. http://dx.doi.org/10.1177/0146167210366306

Chirumbolo, A. (2002). The Relationship between Need for Cognitive Closure and Political Orientation: The Mediating Role of Authoritarianism. Personality and Individual Differences, 32, 603-610. http://dx.doi.org/10.1016/S0191-8869(01)00062-9

Cole, M., Cole, S. R., \& Lightfoot, C. (2005). The Development of Children. New York: Worth.

Crowson, H. M., DeBacker, T. K., \& Thoma, S. J. (2005). Does Authoritarianism Predict Post-9/11 Attitudes? Personality and Individual Differences, 39, 1273-1283. http://dx.doi.org/10.1016/j.paid.2005.06.005

Durrheim, K. (1997). Cognition and Ideology: A Rhetorical Approach to Critical Theory. Theory and Psychology, 7, 749- 
770. http://dx.doi.org/10.1177/0959354397076002

Ekehammar, B., Akrami, N., Gylje, M., \& Zakrisson, I. (2004). What Matters Most to Prejudice: Big Five Personality, Social Dominance Orientation, or Right-Wing Authoritarianism? European Journal of Personality, 18, 463-482. http://dx.doi.org/10.1002/per.526

Emler, N., Renwick, S., \& Malone, B. (1983). The Relationship between Moral Reasoning and Political Orientation. Journal of Personality and Social Psychology, 45, 1073-1080. http://dx.doi.org/10.1037/0022-3514.45.5.1073

Heaven, P. C. L., Ciarrochi, J., \& Leeson, P. (2011). Cognitive Ability, Right-Wing Authoritarianism, and Social Dominance Orientation: A Five-Year Longitudinal Study amongst Adolescents. Intelligence, 39, 15-21. http://dx.doi.org/10.1016/j.intell.2010.12.001

Hodson, G., \& Busseri, M. A. (2012). Bright Minds and Dark Attitudes: Lower Cognitive Ability Predicts Greater Prejudice through Right-Wing Ideology and Low Intergroup Contact. Psychological Science, 23, 187-195. http://dx.doi.org/10.1177/0956797611421206

Hofstede, G. (1991). Cultures and Organizations: Software of the Mind. Maidenhead: McGraw-Hill.

Inhelder, B., \& Piaget, J. (1958). The Growth of Logical Thinking from Childhood to Adolescence. New York: Basic Books. http://dx.doi.org/10.1037/10034-000

Jackson, L. A., \& Jeffers, D. (1989). The Attitudes about Reality Scale: A New Measure of Personal Epistemology. Journal of Personality Assessment, 53, 353-365. http://dx.doi.org/10.1207/s15327752jpa5302_12

Jost, J. T., Federico, C. M., \& Napier, J. L. (2009). Political Ideology: Its Structure, Functions, and Elective Affinities. Annual Review of Psychology, 60, 307-337. http://dx.doi.org/10.1146/annurev.psych.60.110707.163600

Jost, J. T., Glaser, J., Kruglanski, A. W., \& Sulloway, F. J. (2003). Political Conservatism as Motivated Social Cognition. Psychological Bulletin, 129, 339-375. http://dx.doi.org/10.1037/0033-2909.129.3.339

Kail, R. V. (2012). The Development of Memory in Children (3rd ed.). New York: W. H. Freeman.

Kemmelmeirer, M. (2008). Is There a Relationship between Political Orientation and Cognitive Ability? A Test of Three Hypotheses in Two Studies. Personality and Individual Differences, 45, 767-772. http://dx.doi.org/10.1016/i.paid.2008.08.003

Kohlberg, L. (1969). Stage and Sequence: The Cognitive Developmental Approach to Socialization. In D. Goslin, (Ed.), Handbook of Socialization Theory and Research (pp. 347-480). Chicago, IL: Rand McNally.

Krebs, D. L., \& Denton, K. (2005). Toward a More Pragmatic Approach to Morality: A Critical Evaluation of Kohlberg's Model. Psychological Review, 112, 629-649. http://dx.doi.org/10.1037/0033-295X.112.3.629

McCourt, K., Bouchard Jr., T., Lykken, D., Tellegren, A., \& Keyes, M. (1999). Authoritarianism Revised: Genetic and Environmental Influence Examined in Twins Reared Apart and Together. Personality and Individual Differences, 27, 9851014. http://dx.doi.org/10.1016/S0191-8869(99)00048-3

Meehan, A. M. (1984). A Meta-Analysis of Sex Differences in Formal Operational Thought. Child Development, 55, 11101124. http://dx.doi.org/10.2307/1130164

Miller, P. H. (2010). Piaget's Theory: Past, Present, and Future. In U. Goswami, (Ed.), The Wiley-Blackwell Handbook of Childhood Cognitive Development (pp. 649-672). Malden, MA: Wiley-Blackwell.

http://dx.doi.org/10.1002/9781444325485.ch25

Mundy, A. (2004). Divided We Stand. Advertising Age.

http://adage.com/article/american-demographics/divided-stand/44999/

Newman, B. M., \& Newman, P. R. (2007). Theories of Human Development. Mahwah, NJ: Lawrence Erlbaum Associates.

Prezza Technologies, Inc. (2010). CheckBox (Version 4.7) [Computer Software]. Cambridge, MA.

Reyes, D. J. (1987). Cognitive Development of Teacher Candidates: An Analysis. Journal of Teacher Education, 38, $18-21$. http://dx.doi.org/10.1177/002248718703800205

Reykowski, J., \& de Zavala, A. G. (2006). Consequences of Patriotism: Is Ethnocentrism Inevitable? In A. G. de Zavala, \& K. Skarzynska, (Eds.), Understanding Social Change: Political Psychology in Poland (pp. 87-103). New York: Nova Science Publishers.

Schirks, A. (1970). Evaluation des opérationsintellectuellesd'adultesen formation. Unpublished Thesis, Nancy: University of Nancy.

Schoon, I., Cheng, H., Gale, C. R., Batty, G. D., \& Deary, I. J. (2010). Social Status, Cognitive Ability, and Educational Attainment as Predictors of Liberal Social Attitudes and Political Trust. Intelligence, 38, 144-150.

http://dx.doi.org/10.1016/j.intell.2009.09.005

Seyle, D. C., \& Newman, M. L. (2006). A House Divided? The Psychology of Red and Blue America. American Psychologist, 61, 571-580. http://dx.doi.org/10.1037/0003-066X.61.6.571 
Sidanius, J., Pratto, F., \& Bobo, L. (1996). Racism, Conservatism, Affirmative Action, and Intellectual Sophistication: A Matter of Principled Conservatism or Group Dominance? Journal of Personality and Social Psychology, 70, 476-490. http://dx.doi.org/10.1037/0022-3514.70.3.476

Stankov, L. (2009). Conservatism and Cognitive Ability. Intelligence, 37, 294-304. http://dx.doi.org/10.1016/j.intell.2008.12.007

Tetlock, P. E. (1983). Cognitive Style and Political Ideology. Journal of Personality and Social Psychology, 45, 118-126. http://dx.doi.org/10.1037/0022-3514.45.1.118

Thorisdottir, H., Jost, J. T., Liviatan, I., \& Shrout, P. E. (2007). Psychological Needs and Values Underlying Left-Right Political Orientation: Cross-National Evidence from Eastern and Western Europe. Public Opinion Quarterly, 71, 175-203. http://dx.doi.org/10.1093/poq/nfm008

Umbach, P. D., \& Wawrzynski, M. R. (2005). Faculty Do Matter: The Role of College Faculty in Student Learning and Engagement. Research in Higher Education, 46, 153-184. http://dx.doi.org/10.1007/s11162-004-1598-1

Unger, R. K., Draper, R. D., \& Pendergrass, M. L. (1986). Personal Epistemology and Personal Experience. Journal of Social Issues, 42, 67-79. http://dx.doi.org/10.1111/j.1540-4560.1986.tb00225.x 